\title{
Carcinoma in situ and early invasive carcinoma of the bronchus
}

\author{
M.K. MASON A N D J W. JOR D A N \\ From Killingbeck Hospital, Leeds, Yorks
}

Ten patients are described who underwent lobectomy or pneumonectomy and were shown to have a bronchial carcinoma in situ or early invasive carcinoma. The diagnosis was generally made only by histological examination following resection. The lesions were all squamous in type. It is probably uncommon for such lesions to be multifocal at any one time and following removal they carry a good prognosis. However, we think that these patients have a much increased chance of subsequently developing further squamous bronchial carcinomas in the remaining lung tissue, and so a prolonged follow-up over many years is desirable. In our series, these early lesions were present in only $2.0 \%$ of all resections for lung cancer. A group of patients with such early tumours present with disproportionately severe radiographic changes, as there is a papillary lesion producing bronchial obstruction, and so the lesion appears clinically to be more advanced than it really is. A pre-operative diagnosis of carcinoma in situ is more likely in the other group of patients without obstruction, who are heavy smokers, are chronic bronchitics, and are having repeated small haemoptyses. This group presents a problem in management and requires careful observation. Investigations for finding early lesions include regular cytological examination of the sputum, followed by bronchoscopy in an attempt to localize the lesion if cytology is positive. Lobectomy or pneumonectomy should be undertaken when the site is established.

The first reported surgical resection of a bronchial carcinoma in situ was by Umiker and Storey (1952). Since then several series have been reported, often showing successful excision of the lesion (Wierman, McDonald, and Clagett, 1954 ; Woolner, Andersen, and Bernatz, 1960 ; Lerner, Rosbash, Frank, and Fleischner, 1961 ; Melamed, Koss, and Cliffton, 1963 ; Pearson and Thompson, 1966). It is apparent that comparatively few patients are diagnosed at this early stage but that treatment can be very effective. This paper presents the clinical and pathological findings in a series of 10 patients who underwent pneumonectomy or lobectomy and were found to have a carcinoma at an early stage of development.

\section{MATERIALS AND METHODS}

All except one of the specimens were removed during the three years 1964 to 1966 inclusive. The series comprises those specimens in which there was either a carcinoma in situ or a small carcinoma with some invasion within the mucosa. No cases were included if infiltration had progressed beyond the bronchial wall. Resected specimens were fixed immediately after removal by filling the bronchi with formal saline run in from above and then immersing the lung overnight in formal saline. One patient had undergone lobectomy elsewhere 16 years previously and only the sections and case notes were available.

T A B L E I

PRESENTING FEATURES

\begin{tabular}{|c|c|c|c|}
\hline $\begin{array}{l}\text { Case No. } \\
\text { and Sex }\end{array}$ & Age (yrs) & $\begin{array}{l}\text { Presenting Symptom } \\
\text { and Duration }\end{array}$ & Smoking Habits \\
\hline $\begin{array}{ll}1 & \mathbf{M} \\
2 & \mathbf{M}\end{array}$ & $\begin{array}{l}59 \\
63\end{array}$ & $\begin{array}{l}\text { Hoarseness, } 6 \text { weeks } \\
\text { Cough and haemoptysis } \\
\text { after acute bronchitis } \\
6 \text { months }\end{array}$ & $\begin{array}{l}20 \text { cigarettes/day } \\
\text { Not known }\end{array}$ \\
\hline $3 \mathbf{M}$ & 67 & $\begin{array}{l}\text { Cough and chest pain, } \\
5 \text { months }\end{array}$ & 20 cigarettes/day \\
\hline $\begin{array}{ll}4 & M \\
5 & M \\
6 & M\end{array}$ & $\begin{array}{l}61 \\
68 \\
56\end{array}$ & $\begin{array}{l}\text { Chest pain, } 6 \text { weeks } \\
\text { Cough, } 6 \text { weeks } \\
\text { Chest injury following } \\
\text { a recent fall, Brief }\end{array}$ & $\begin{array}{l}30 \text { cigarettes/day } \\
50 \text { cigarettes/day } \\
20 \text { cigarettes/day }\end{array}$ \\
\hline $7 \mathbf{M}$ & 58 & $\begin{array}{l}\text { Chest pain and cough } \\
3 \text { weeks }\end{array}$ & 30 cigarettes/day \\
\hline & 46 & $\begin{array}{l}\text { Chest pain and cough, } \\
8 \text { weeks }\end{array}$ & Not known \\
\hline $9 \mathbf{M}$ & 60 & $\begin{array}{l}\text { Recurrent haemoptysis } \\
6 \text { weeks }\end{array}$ & $\begin{array}{l}\text { Pipe smoker, } \\
3 \mathrm{oz} . / \text { week }\end{array}$ \\
\hline $10 \mathrm{M}$ & $\begin{array}{c}52 \\
\text { (at } \\
\text { operation) }\end{array}$ & $\begin{array}{l}\text { Cough, sputum and } \\
\text { haemoptysis, } 5 \text { months }\end{array}$ & 30 cigarettes/day \\
\hline
\end{tabular}




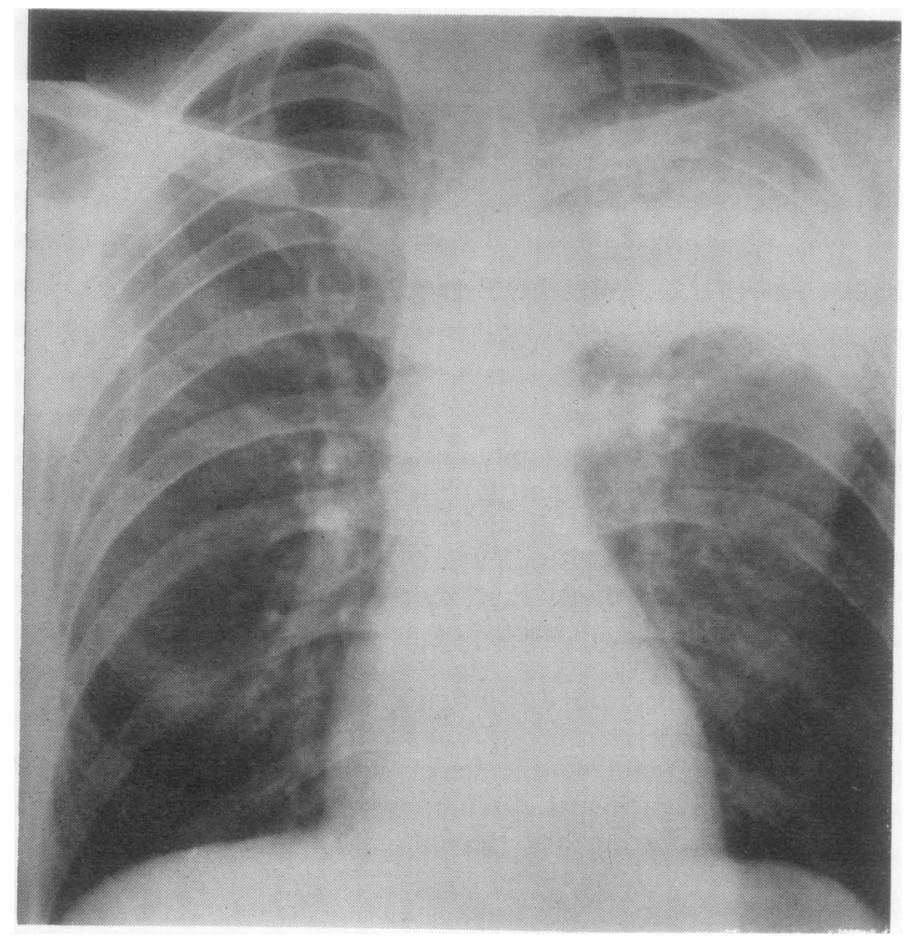

FIG. 1. Opacity due to obstruction left upper lobe bronchus by small papillaty. tumour (Case 7).

FIG. 2. Fullness of left hilum only. Carcinoma in situ of left main bronchus (Case 9).

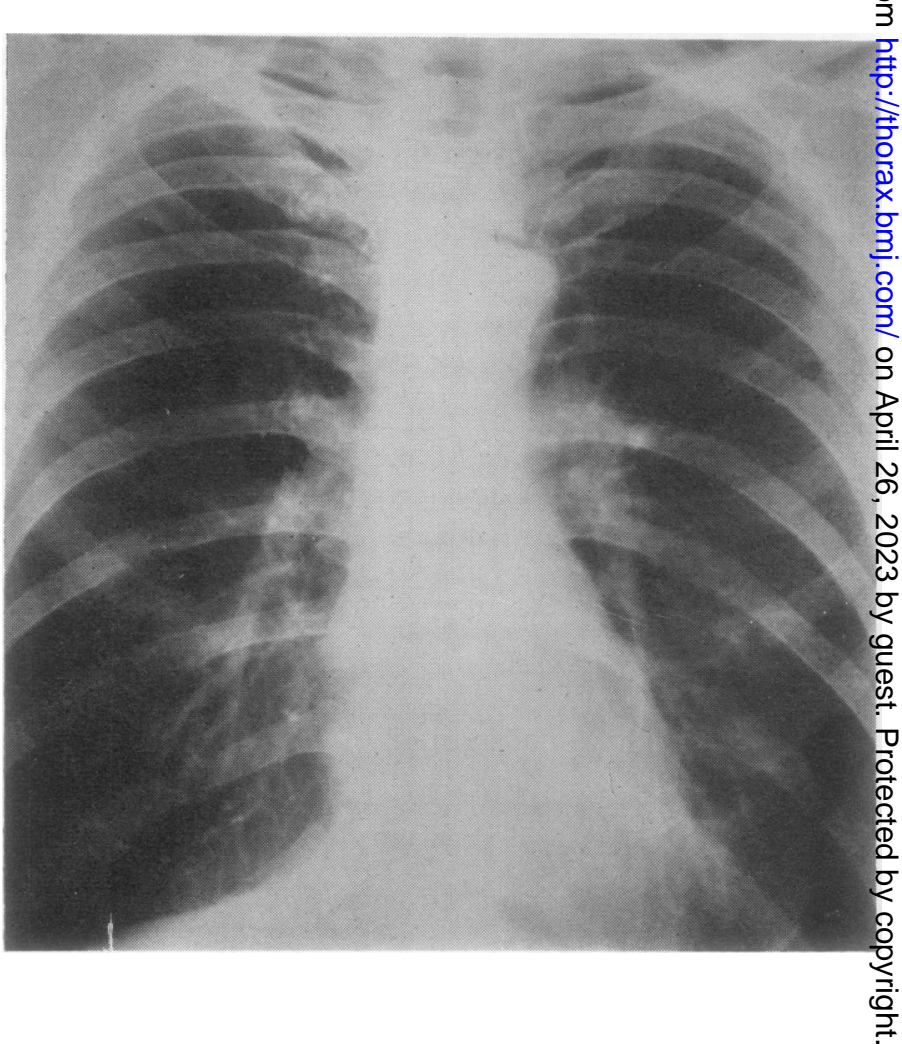




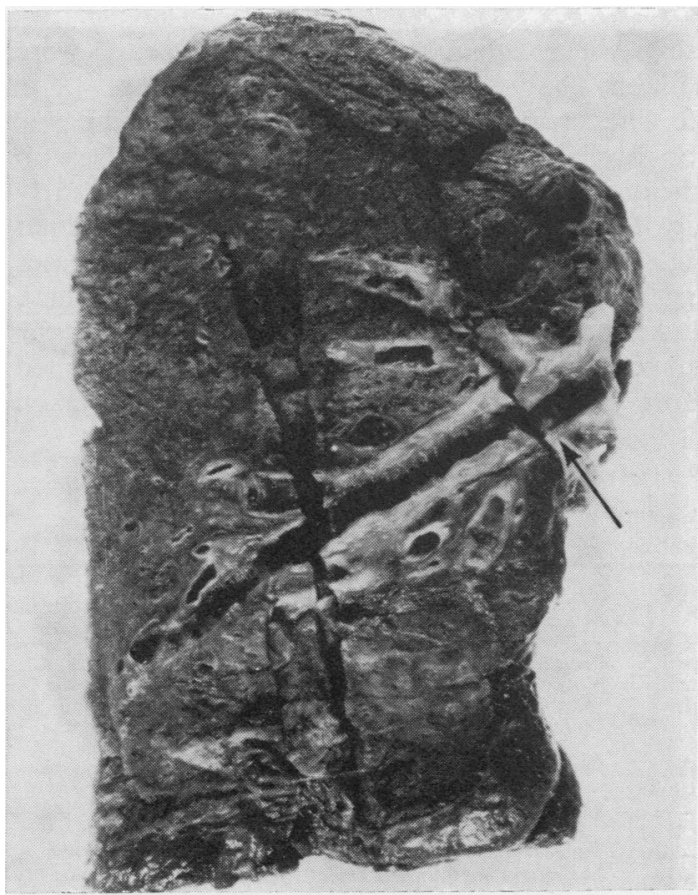

FIG. 3. Small intra-bronchial tumour in right lower lobe bronchus with distal bronchiectasis (Case 4).

FIG. 4. Carcinoma in situ, with involvement of some of the glands. Bronchoscopically mucosa appeared granular (Case 9). $\times 50$

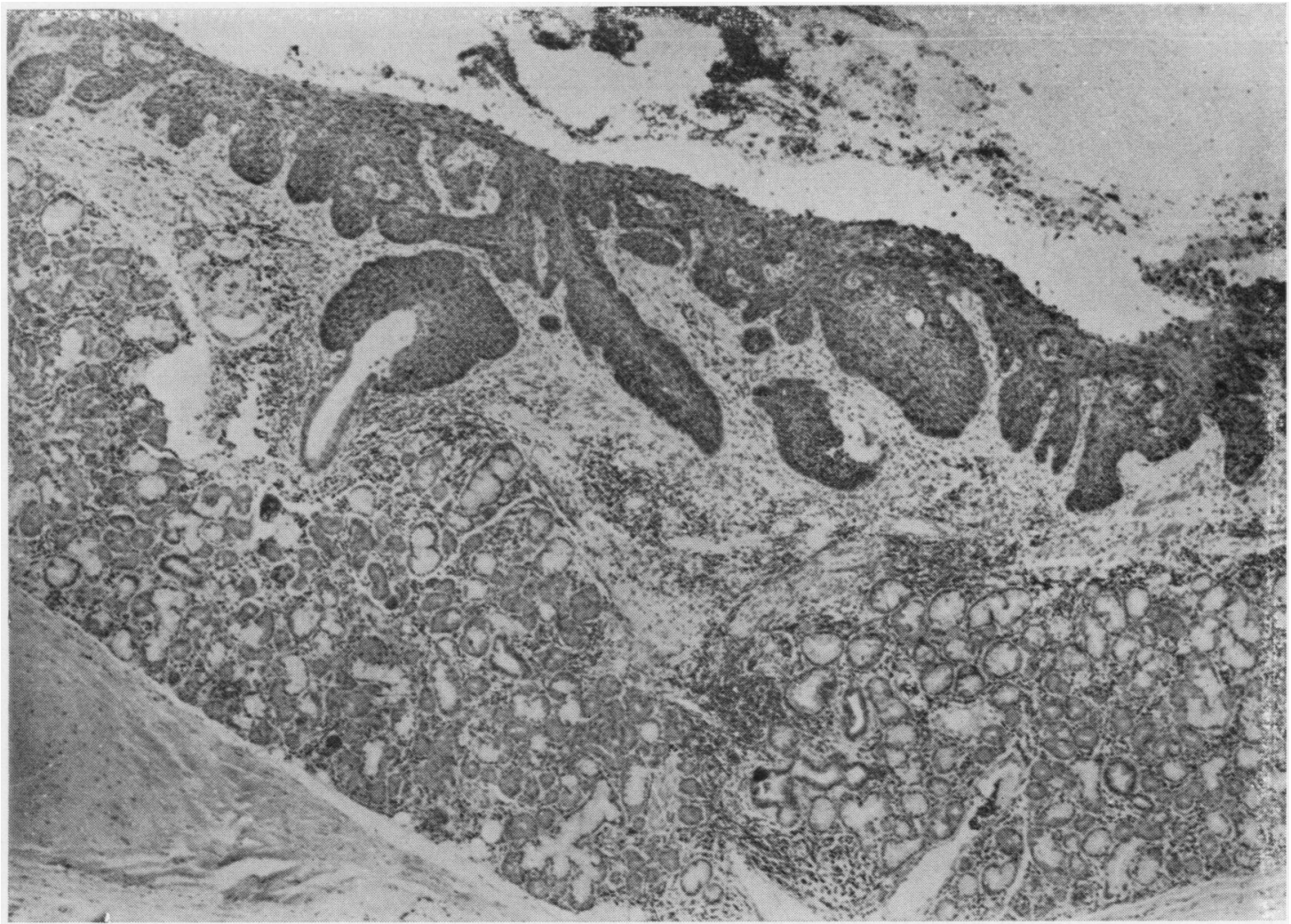




\section{CLINICAL FEATURES}

The detailed findings are shown in Tables I to III. The main features are summarized as follows:

1. The usual presenting symptoms were cough and/or haemoptysis and chest pain. Recent symptoms had usually been present for less than two months, the longest history given being six months. In addition, the majority of patients had suffered from 'chronic bronchitis' for years. Patients were found to be heavy smokers in all cases where adequate smoking histories were available (Table I).

2. Chest radiographs were abnormal in all cases, probably because of neoplasm, but there was now indication that the lesions were relatively earlyळ (Fig. 1); in two cases the changes were minimalo (Fig. 2). Bronchoscopic findings in most cases suggested carcinoma but were sometimes normal.. Squamous cancer cells were found in two of the $\overrightarrow{-}$ four cases in which the sputum was examined before operation. Bronchial biopsies were taken $\underset{\times}{x}$

T A B L E I I

INVESTIGATIONS

\begin{tabular}{|c|c|c|c|c|}
\hline $\begin{array}{l}\text { Case No. } \\
\text { and Sex }\end{array}$ & Chest Radiograph & Cytology & Bronchoscopy & Biopsy \\
\hline $\begin{array}{ll}1 & \mathbf{M} \\
2 & \mathbf{M}\end{array}$ & $\begin{array}{l}\text { Irregular left upper zone opacity } \\
\text { Opacity from upper pole of left hilum }\end{array}$ & $\begin{array}{l}\text { Sputum + ve } \\
\text { Sputum - ve } \\
\text { ( } 2 \text { specimens })\end{array}$ & $\begin{array}{l}\text { Pedunculated mass left side } \\
\text { Normal }\end{array}$ & $\begin{array}{l}\text { Carcinoma } \\
\text { Not done }\end{array}$ \\
\hline $3 \mathbf{M}$ & $\begin{array}{l}\text { Consolidation and collapse of left lower } \\
\text { lobe }\end{array}$ & Not done & Widespread infiltration of left bronchus & Carcinoma \\
\hline $4 \mathbf{M}$ & Retrocardiac atelectasis (? neoplasm) & $\begin{array}{l}\text { Sputum - ve } \\
\text { (2 specimens) }\end{array}$ & $\begin{array}{l}\text { Probable carcinoma of right lower } \\
\text { lobe }\end{array}$ & Carcinoma \\
\hline & Encysted effusion ? abscess ? neoplasm & Secretions - ve & $\begin{array}{l}\text { Left bronchus bled easily; no definite } \\
\text { malignancy }\end{array}$ & Carcinoma \\
\hline $\begin{array}{ll}6 & \mathrm{M} \\
7 & \mathrm{M} \\
8 & \mathrm{~F}\end{array}$ & $\begin{array}{l}\text { ? Left neoplasm } \\
\text { Mass in left upper lobe-carcinoma } \\
\text { Enlarged left hilum. Opacity in pectoral } \\
\text { segment of left upper lobe on tomography }\end{array}$ & $\begin{array}{l}\text { Secretions - ve } \\
\text { Secretions + ve } \\
\text { Sputum + ve } \\
\text { Secretions + ve }\end{array}$ & $\begin{array}{l}\text { Funnel-type bronchial stenosis } \\
\text { Malignant mass in left upper lobe } \\
\text { Normal }\end{array}$ & $\begin{array}{l}\text { Negative } \\
\text { Not done } \\
\text { Negative }\end{array}$ \\
\hline $\begin{aligned} 9 \mathrm{M} \\
10 \mathrm{M}\end{aligned}$ & $\begin{array}{l}\text { Fullness of left hilum } \\
\text { Collapse of left upper lobe (at time of } \\
\text { operation) }\end{array}$ & $\begin{array}{l}\text { Not done } \\
\text { Not done }\end{array}$ & $\begin{array}{l}\text { Grey area in left upper lobe bronchus } \\
\text { Malignant }\end{array}$ & $\begin{array}{l}\text { Not done } \\
\text { Not done }\end{array}$ \\
\hline
\end{tabular}

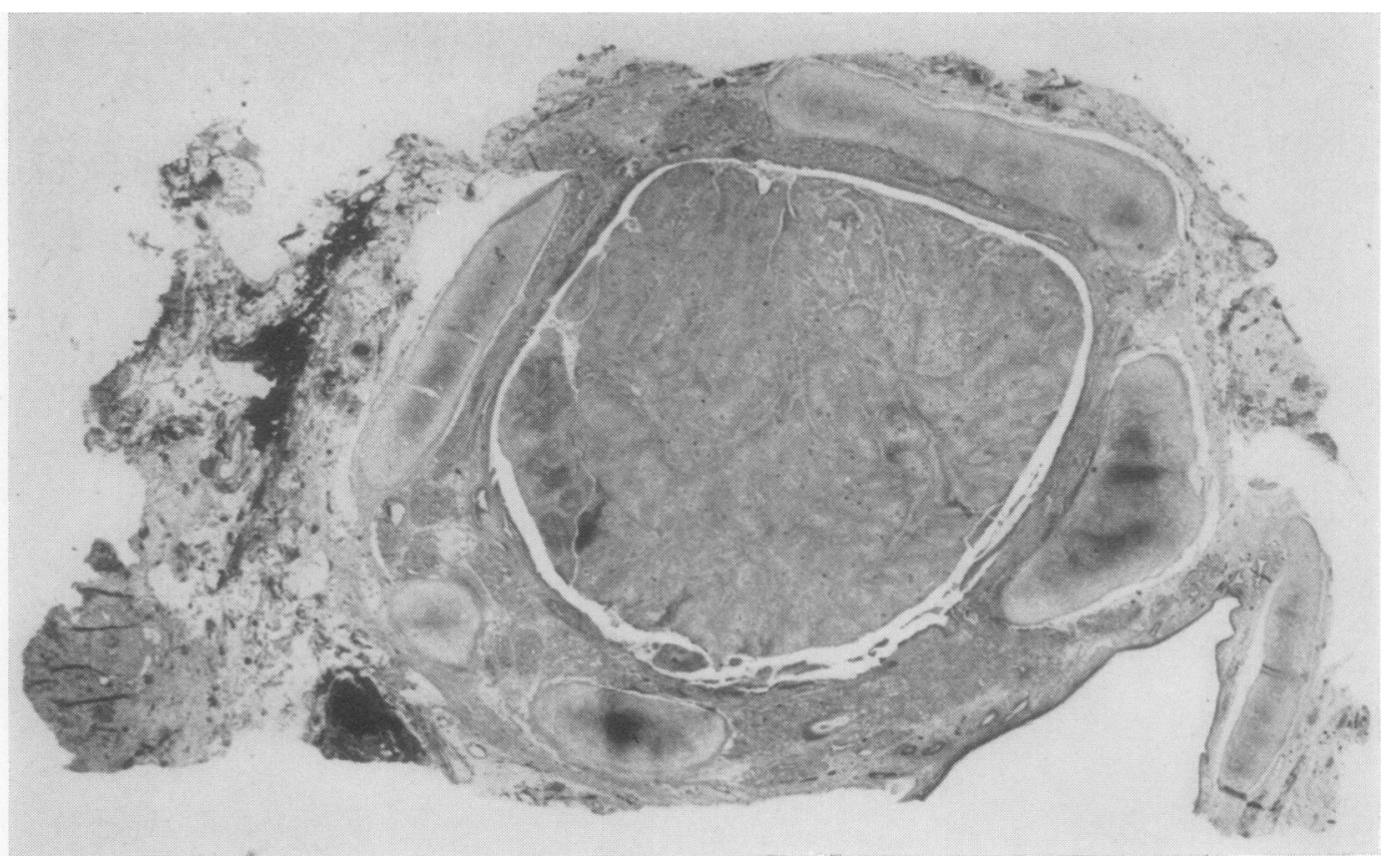

FIG. 5. Papillary tumour occluding the bronchus (Case 3$). \times 6$. 


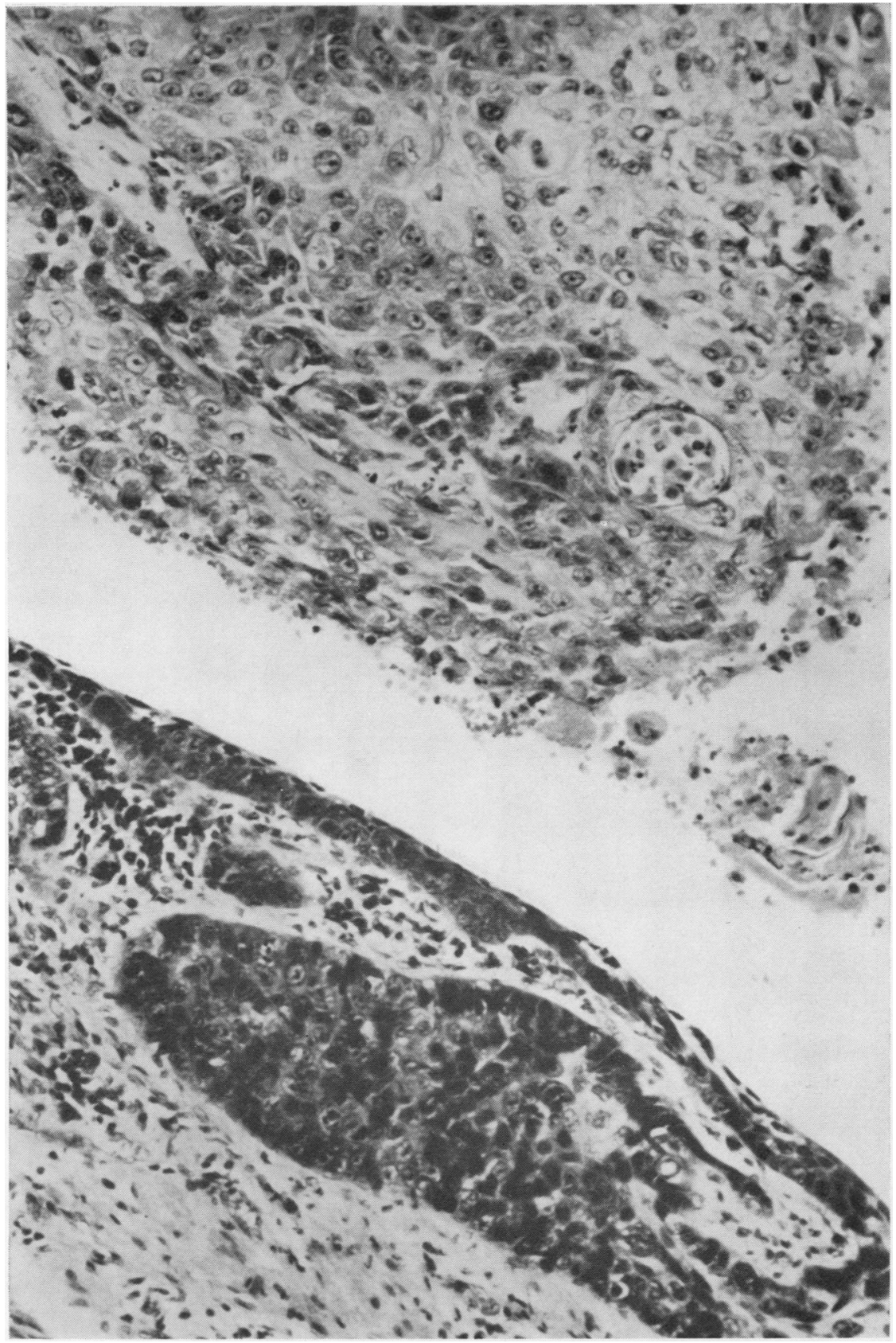

FIG. 6. High-power view from Fig. 5: papillary tumour above and bronchial wall below (Case 3). $\times 375$. 

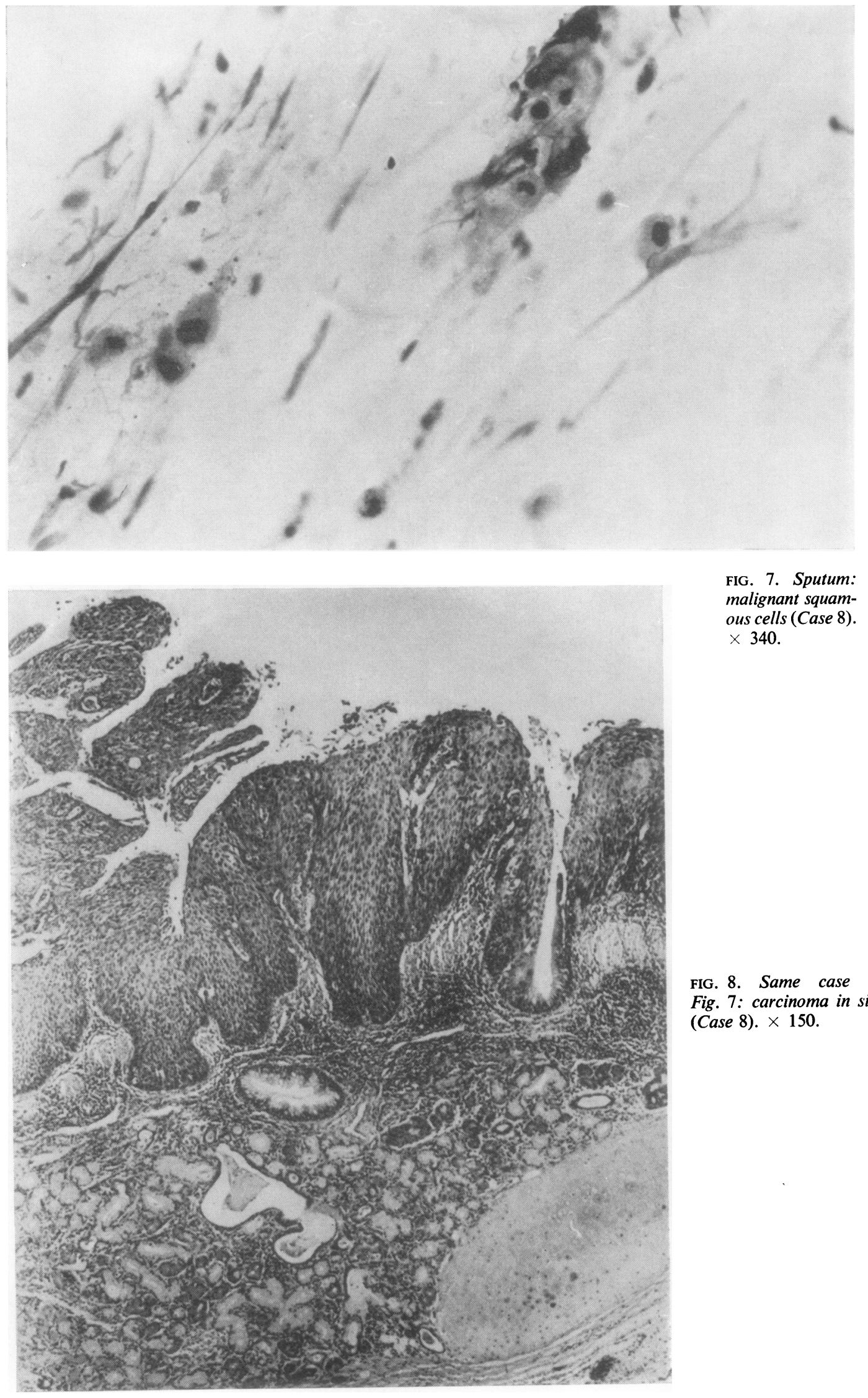

FIG. 7. Sputum: malignant squamous cells (Case 8).

$\times 340$.

IG. 8. Same case as Fig. 7: carcinoma in situ (Case 8). $\times 150$. 


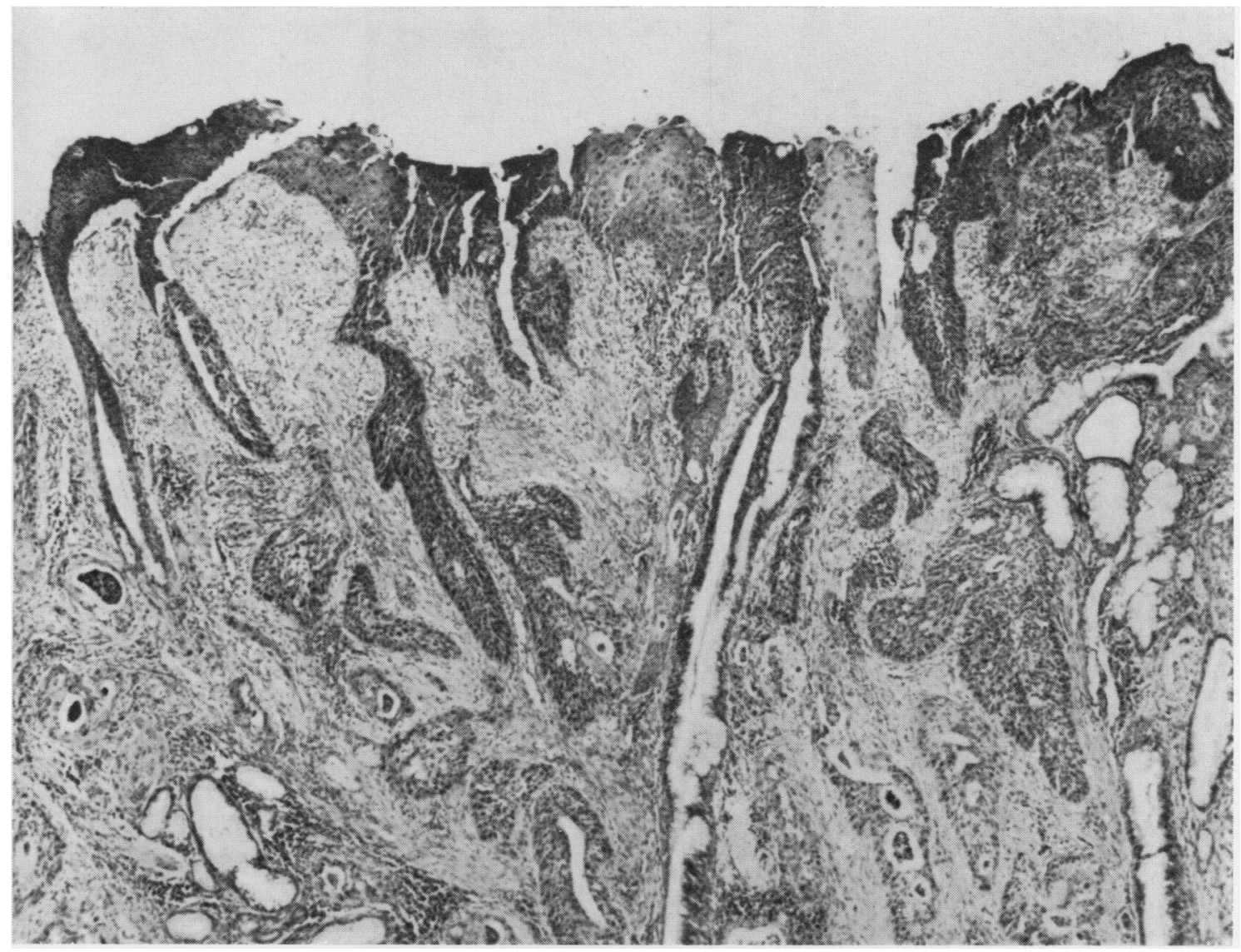

FIG. 9. Infiltration within the bronchial mucosa (Case 1). $\times 150$.

T A B L E I I I

SPECIMEN AND SUBSEQUENT COURSE

\begin{tabular}{|c|c|c|c|}
\hline $\begin{array}{l}\text { Case No. } \\
\text { and Sex }\end{array}$ & Operation & Specimen & Outcome \\
\hline $1 \mathbf{M}$ & Left pneumonectomy & $\begin{array}{l}\text { Two separate papillary tumours in } \\
\text { L.U.L. bronchus }\end{array}$ & Alive and well 8 months later \\
\hline $2 \mathbf{M}$ & Left upper lobectomy & Granularity of bronchial mucosa in & Died 34 months later of broncho- \\
\hline $3 \mathbf{M}$ & Left pneumonectomy & $\begin{array}{l}\text { Intra-bronchial mass in left main } \\
\text { bronchus. Distal bronchiectasis }\end{array}$ & Alive and well 33 months later \\
\hline $4 \mathrm{M}$ & Right middle and lower lobectomy & Intra-bronchial mass in R.L.L. & Alive and well 17 months later \\
\hline $5 \mathrm{M}$ & Left pneumonectomy & $\begin{array}{l}\text { Small intra-bronchial mass and } \\
\text { granular mucosa in L.L.L. bronchus. } \\
\text { Some distal bronchiectasis. Empyema }\end{array}$ & Alive and well 43 months later \\
\hline $6 \mathrm{M}$ & Left pneumonectomy & $\begin{array}{l}\text { Thickening of mucosa in L.U.L. } \\
\text { bronchus. Slight distal bronchiectasis } \\
\text { and infection }\end{array}$ & $\begin{array}{l}\text { Died } 23 \text { months later from cerebral } \\
\text { haemorrhage. No evidence of } \\
\text { carcinoma }\end{array}$ \\
\hline $7 \mathbf{M}$ & Left pneumonectomy & $\begin{array}{l}\text { Intra-bronchial mass in L.U.L. } \\
\text { bronchus. Distal bronchiectasis and } \\
\text { infection }\end{array}$ & Alive and well 25 months later \\
\hline & Left upper lobectomy & $\begin{array}{l}\text { Small intra-bronchial nodule. } \\
\text { No obstruction }\end{array}$ & Post-operative death \\
\hline $9 \mathrm{M}$ & Left pneumonectomy & $\begin{array}{l}\text { Granularity of left main bronchus. } \\
\text { No bronchiectasis }\end{array}$ & $\begin{array}{l}\text { Alive and well } 36 \text { months later but } \\
\text { carcinoma in situ (biopsy positive) in }\end{array}$ \\
\hline $10 \mathrm{M}$ & Left upper lobectomy & $\begin{array}{l}\text { Granular bronchial mucosa. Slight } \\
\text { distal bronchiectasis }\end{array}$ & $\begin{array}{l}\text { right main bronchus since operation } \\
\text { Died from presumed second carcinoma } \\
\text { of right lung } 16 \text { years later }\end{array}$ \\
\hline
\end{tabular}




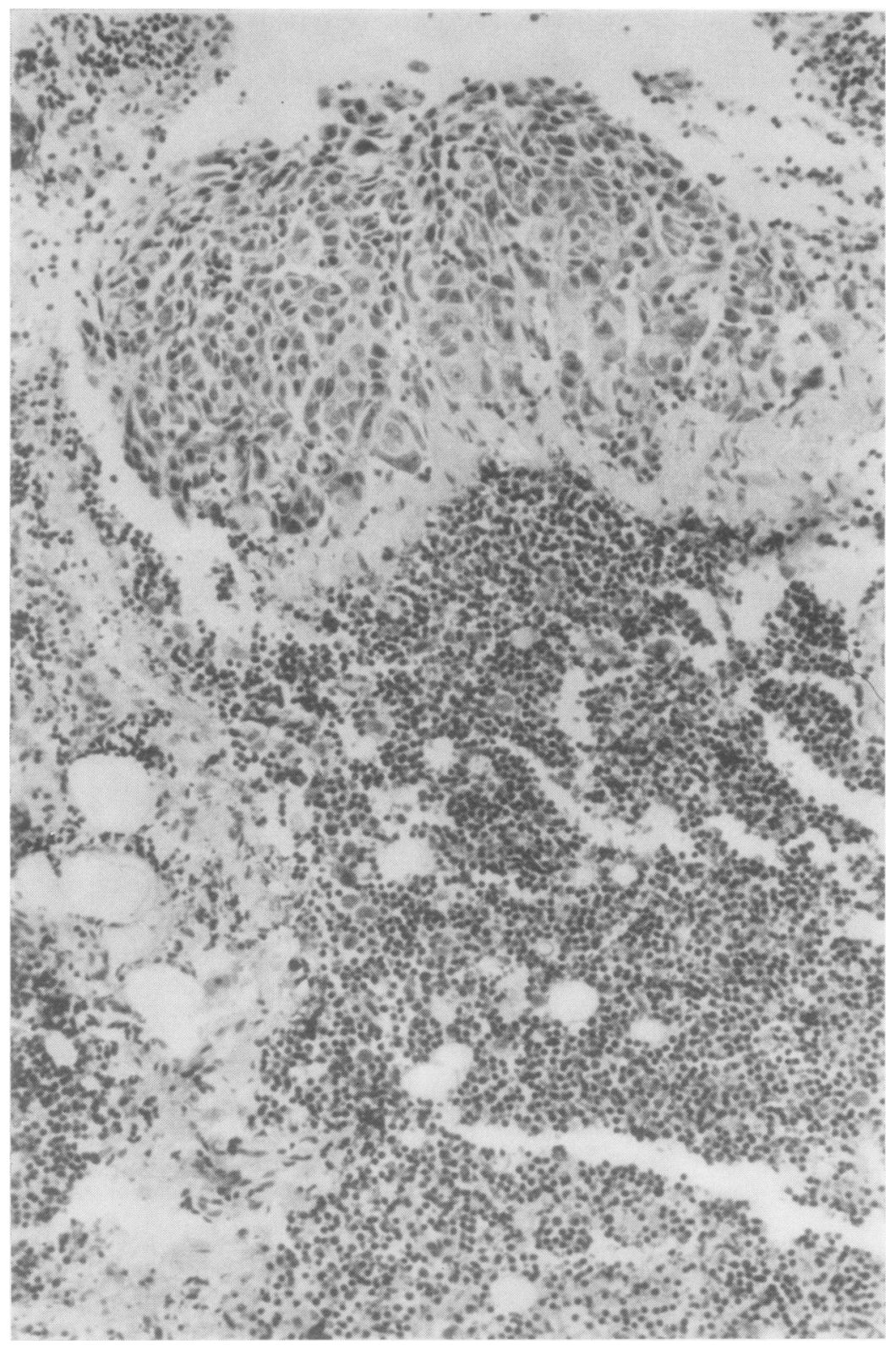

FIG. 10. Small metastasis at periphery of hilar lymph node (Case 6). $\times 150$.

in six cases and were positive in four (Table II).

3. Six of the first nine patients operated on have survived. None of the patients who died showed evidence of recurrence. A fourth death (case 10) was due to a carcinoma in the other lung which developed 16 years after lobectomy for a carcinoma in situ. It seems likely that this represented a second primary tumour (Table III).

\section{PATHOLOGICAL FEATURES}

GROSS APPEARANCE The tumours, with one excep- $\frac{0}{0}$ tion, were situated in the left bronchial tree. In $\frac{\mathbb{D}}{\mathbb{D}}$

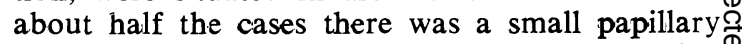
tumour, which was partly or completely occluding 2 the lumen of the bronchus (Fig. 3) and producingo distal bronchiectasis and pneumonia, often gross (Table III). 
In the remaining cases the mucosa either presented a rather granular appearance or there was slight thickening of the bronchial wall at the site of the lesion (Fig. 4).

HISTOLOGICAL TYPE OF TUMOUR All were squamous-cell carcinomas. In six cases these were in the form of a papillary tumour (Figs 5 and 6). In the remaining four cases with a granular mucosa there was a straightforward change in the epithelium to carcinoma in situ. Squamous metaplasia or carcinoma in situ of some of the underlying bronchial glands was seen in all cases, in addition to the changes in the surface epithelium. The atypical cells in the sputum were characteristic of malignant squamous cells (Figs 7 and 8).

INVASION Limited invasion was found in five cases (Fig. 9), but this had not progressed beyond the bronchial wall except in case 6 , where, in addition to submucosal invasion, a small metastasis was found in the afferent lymphatic of a hilar lymph node (Fig. 10).
INCIDENCE Eight of the cases in this series were found in three years from a total of 403 pneumonectomies or labectomies for lung carcinoma. Thus, less than $2.0 \%$ of resectable lung cancers are being found at this early stage.

\section{DISCUSSION}

NATURAL HISTORY OF BRONCHIAL CARCINOMA IN SITU It is generally accepted that carcinoma in situ frequently progresses to invasive carcinoma after a variable period of time. The diagnosis of the condition during life is therefore important, although in the case of the bronchus it seems probable that it is made only in patients with either a relatively slowly growing lesion or with a polypoid tumour producing obstruction. All the reported carcinomas in situ have been squamous in type and have presumably arisen in foci of squamous metaplasia. The prognosis where minimal invasion is present appears to be similar to that of a lesion which is strictly in situ. By analogy with the stomach (Mason, 1965), it is possible that the prognosis may still be good even when a

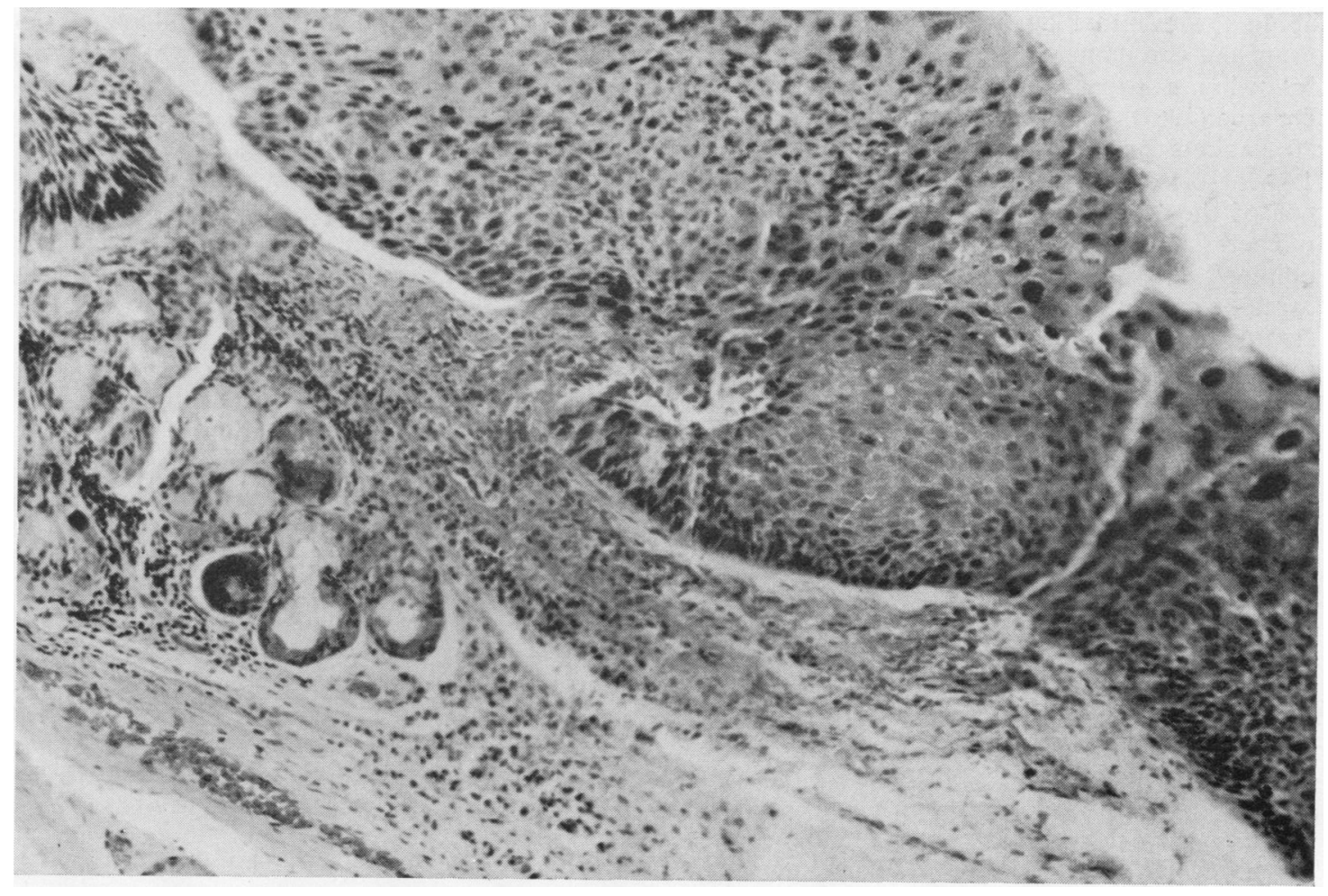

FIG. 11. Bronchial carcinoma in situ: operation specimen (Case 10). $\times 375$. 
small metastasis is present in the afferent lymphatics of a regional node, as in case 6 .

The good prognosis following adequate surgical excision of the lesion has been described by both Woolner et al. (1960) and Pearson and Thompson (1966); the findings in the present series support this view. From this series two main prognostic points emerge: the first is that an in situ carcinoma may have a prolonged course, as in case 9 , in whom carcinoma in situ is present in the main bronchus of the remaining lung. This type of behaviour is emphasized by Lerner et al. (1961) and is well illustrated by this case, as there is still no evidence of invasion three years after operation. It seems more likely that the original lesion was incompletely removed in this patient, rather than that a second focus of carcinoma in situ developed, because carcinoma in situ was seen at the line of resection in the specimen.

The second prognostic point is that there is a risk of a second carcinoma developing, sometimes many years later. This is illustrated by case 10 , who died from a squamous carcinoma developing in the opposite lung 16 years after a lobectomy for carcinoma in situ (Fig. 11). Little is known about the eventual outcome after resection of a bronchial carcinoma in situ, but in the discussion following a paper by Pearson, Thompson, and Delarue (1967), Pool reported a follow-up of some 20 patients operated on for very early lesions. Two of these patients developed second tumours, one of them eight years later.

There has been considerable difference of opinion regarding the frequency of bronchial carcinoma in situ. Cunningham and Winstanley (1959), in a necropsy series, thought that it was rare. Similarly, Pearson and Thompson (1966) rare'y detected multiple lesions in surgically removed specimens. On the other hand, Auerbach, Gere, Pawlowski, Muehsam, Smolin, and Stout (1957) reported carcinoma in situ elsewhere in the bronchial tree in 48 of 54 necropsies on men who had died of bronchial cancer and considered that it was often multifocal. Pearson and Thompson, however, felt that the criteria used by Auerbach et al. for the diagnosis of carcinoma in situ were not sufficiently strict. In the present series carcinoma in situ elsewhere in the bronchial tree was found in two of the 10 cases. The number of cases is small but we consider that multifocal lesions are relatively uncommon at any one time in the bronchial tree. However, since the whole of the bronchial tree is presumably at risk, we suggest that a considerable proportion of survivors after resection of an early cancer will eventually develop further squamous cancers, especially i smoking is continued. It should also be remem? bered in this context that the development of second primary lung cancer following lobectom for an invasive tumour is being recognized mor\& frequently (Abbey Smith, 1966).

CliniCal DIAGNOSIS AND MANAGEMENT These $1 \vec{\rho}$ cases of carcinoma in situ or early invasive carci $\overrightarrow{\vec{\omega}}$ noma have many features in common with franle invasive carcinoma of the bronchus:

(1) sex incidence (only one being female);

(2) age distribution (46-68 years) ;

(3) presenting symptoms (except that in many cases their duration was brief);

(4) smoking history.

A diagnosis of carcinoma in situ was made pre operatively in only one case, although the bronchoscopic findings suggested in some cases that a carcinoma in situ might be present. It is $\vec{s}$ not possible to differentiate cytologically betweene carcinoma in situ and invasive cancer.

From both the clinical and pathological point of view the patients fall into two groups, depend ing on whether there is bronchial obstruction. Ing the first group the presence of a papillary tumoug produces bronchial obstruction with distal col lapse and infection which is often severe. Because an intrabronchial mass is found at bronchoscopys and chest radiographic changes are gross, these lesions appear much more advanced than the really are. In the second group of patients withou an intrabronchial nodule, diagnosis is much moren difficult, as the radiological changes are minima or absent. These patients frequently present witb. repeated small haemoptyses; abnormal bronchos scopic findings, such as a granular mucosa which bleeds readily, are present only when the lesiono is relatively proximal in situation.

The importance of suspecting carcinoma ing patients with an unresolved pneumonia mus again be emphasized. Of equal importance is the possibility of an early carcinoma in patients witt unexplained haemoptysis. The type of patient in whom an early carcinoma, either obstructing of non-obstructing, is most likely to be found is the् same as for invasive carcinoma, i.e., the middle aged or elderly man who is a heavy cigarette smoker, has repeated haemoptyses, and may hav: chronic bronchitis. It is essential to watch thi type of case most carefully and make repeate $\overrightarrow{\mathrm{P}}$ and adequate examination of the sputum for malignant cells. These should be repeated at nof more than six-monthly intervals; Pearson et ak (1967) consider that three-monthly intervals are 
preferable. The finding of malignant cells or a change in the chest radiographs is an indication for bronchoscopy in an attempt to localize the lesion. This may not be difficult if it involves a bronchus which is visible at bronchoscopy and a biopsy can be taken from a doubtful area, but in other cases there may be a major problem, as one has to depend on differential suckings from various bronchial orifices, as in case 8 . This is not entirely reliable as malignant cells may not be found and there is also a risk of cross contamination between different orifices (Pearson et al., 1967). Although complete cytological studies were undertaken in only two cases in this series, cytology is quite successful in detecting bronchial carcinomas in situ and has been used effectively by other workers (Woolner et al., 1960 ; Lerner et al., 1961 ; Melamed et al., 1963 ; Pearson et al., 1967).

TREATMENT There seems little doubt that an adequate resection is the desirable course when a bronchial carcinoma in situ is suspected. This should be as conservative as the site of the lesion permits and, where possible, a lobectomy should be done rather than a pneumonectomy. It is obviously essential that there must be accurate localization before operation is considered, as there will often be no palpable evidence of tumour at thoracotomy.

FOLLOW-UP Because of the risk of a further primary tumour developing, which could also be resectable, a prolonged follow-up extending over many years is essential. This should include regular clinical and radiological investigation, together with examination of the sputum for malignant cells. Bronchoscopy might be required if an abnormality is found.

We thank our medical and surgical colleagues at Killingbeck Hospital and other hospitals in the region who have made their records freely available to us. We are indebted to Professor H. Spencer for his helpful suggestions. We are grateful to the Department of Medical Photography, St. James's Hospital, Leeds, for the illustrations.

\section{REFERENCES}

Auerbach, O., Gere, J. B., Pawlowski, J. M., Muehsam, G. E., Smolin, H. J., and Stout, A. P. (1957). Carcinoma-in-situ and early invasive carcinoma occurring in the tracheobronchial trees in cases of bronchial carcinoma. J. thorac. Surg., 34, 298.

Cunningham, G. J., and Winstanley, D. P. (1959). Hyperplasia and metaplasia in the bronchial epithelium. Ann. roy. Coll. Surg. Engl., 24, 323.

Lerner, M. A., Rosbash, H., Frank, H. A., and Fleischner, F. G. (1961). Radiologic localization and management of cytologically discovered bronchial carcinoma. New Engl. J. Med., 264, 480.

Mason, M. K. (1955). Surface carcinoma of the stomach. Gut, 6, 185.

Melamed, M. R., Koss, L. G., and Cliffton, E. E. (1963). Roentgenologically occult lung cancer diagnosed by cytology. Cancer (Philad.), 16, 1537.

Pearson, F. G., and Thompson, D. W. (1966). Occult carcinoma of the bronchus. Canad. med. Ass. J., 94, 825.

and Delarue, N. C. (1967). Experience with the cytologic detection, localization, and treatment of radiographically undemonstrable bronchial carcinoma. J. thorac. cardiovasc. Surg., 54, 371.

Smith, R. Abbey (1966). Development and treatment of fresh lung carcinoma after successful lobectomy. Thorax, 21, 1 .

Umiker, W., and Storey, C. (1952). Bronchogenic carcinoma in situ: report of a case with positive biopsy, cytological examination, and lobectomy. Cancer (Philad.), 5, 369 .

Wierman, W. H., McDonald, J. R., and Clagett, O. T. (1954). Occult carcinoma of the major bronchi. Surgery, 35, 335 .

Woolner, L. B., Andersen, H. A., and Bernatz, P. E. (1960). "Occult" carcinoma of the bronchus: A study of 15 cases of in situ or early invasive bronchogenic carcinoma. Dis. Chest, 37, 278. 